\title{
OVINOS ALIMENTADOS COM BAGAÇO DE CANA-DE-AÇÚCAR TRATADO COM AMÔNIA ANIDRA
}

\author{
Dayana Alves da Costa \\ Eloísa de Oliveira Simões Saliba \\ Antônio Arnaldo Costa Santana
}

COSTA, D. A. da; SALIBA, E. de O. S.; SANTANA, A. A. C. Ovinos alimentados com bagaço de cana-de-açucar tratado com amônia anidra. Arq. Ciênc. Vet. Zool. UNIPAR, Umuarama, v. 17, n. 4, p. 269-270, out./dez. 2014.

\begin{abstract}
RESUMO: Entre os co-produtos existentes, o bagaço de cana-de-açúcar merece destaque, visto que são produzidas, anualmente no país, cerca de 75 milhões de toneladas por ano. Este bagaço proveniente de usinas de açúcar, álcool ou aguardente constitui um problema, por ser pouco utilizado, sendo muitas vezes queimado ao ar livre, enquanto poderia ser usado na alimentação de ruminantes. Neste estudo, objetivou-se avaliar o efeito da adição da amônia anidra ( $\left.\mathrm{NH}_{3}\right)$ sobre o valor nutritivo do bagaço de cana-de-açúcar (Saccharum officinarum L.) em quatro carneiros adultos machos, castrados, sem raça definida, com peso inicial de 40,75 $\mathrm{kg}$ mantidos em gaiolas individuais de metabolismo, com sal mineralizado e água ad libitum. Quatro dietas isoproteicas, foram testadas e fornecidas aos animais em um delineamento em quadrado latino 4x4, sendo: Dieta 1 - Bagaço de cana-de-açúcar "in natura", Dieta 2 - Bagaço de cana-de-açúcar $+2 \%$ de $\mathrm{NH}_{3}$, com base na matéria seca (MS), Dieta 3 - Bagaço de cana-de-açúcar $+3 \%$ de $\mathrm{NH}_{3}$, com base na MS, Dieta 4 - Bagaço de cana-de-açúcar $+4 \%$ de $\mathrm{NH}_{3}$, com base na MS. As dietas eram fornecidas duas vezes ao dia no período da manhã e tarde sempre nos horários de oito e 16 horas, respectivamente. Para a determinação da digestibilidade aparente utilizaram-se bolsas coletoras de fezes e as amostras do alimento e sobras eram mensuradas diariamente. A coleta da urina foi realizada utilizando-se baldes localizados sob as gaiolas de metabolismo, cujos baldes continham $100 \mathrm{~mL}$ de ácido clorídrico (HCL 2N) para prevenir fermentação e perda de nitrogênio. As amostras coletadas dos alimentos, sobras, fezes e urina foram acondicionadas em recipientes plásticos e conservadas em refrigeração, separando-se as amostras por tratamento e período experimental. Após descongelamento, as amostras de fezes, da dieta e suas respectivas sobras foram pré-secas em estufa a $55^{\circ} \mathrm{C}$ durante 72 horas, e posteriormente, moídas em moinha com peneira de malha $1,00 \mathrm{~mm}$. As amostras de urina foram previamente desidratadas em estufa a $55^{\circ}$ $\mathrm{C}$ acondicionadas em recipientes plásticos e posteriormente colocadas em calorímetro, para determinação do conteúdo energético. Os resultados do consumo e digestibilidade foram submetidos à análise de variância, seguido de pós Teste Student-Newman-Kewls com nível de significância de 5\%. O consumo e digestibilidade da matéria seca (MS), proteína bruta (PB), energia bruta (EB) e energia metabolizável (EM) não diferiu entre os tratamentos $(\mathrm{P}>0,05)$. A digestibilidade e o consumo expresso em $\left(\mathrm{g} / \mathrm{kg}^{0,75}\right)$ da fibra em detergente neutro (FDN) foram de 51,1 e 17,2; 50,9 e 26,1; 52,14 e 19,2; 58,3 e 21,0. A digestibilidade da fibra em detergente ácido (FDA) no tratamento com 4\% de $\mathrm{NH}_{3}$ foi superior $(59,5 \%)$ ao tratamento sem adição de $\mathrm{NH}_{3}(50,9 \%)$. A digestibilidade da celulose no tratamento sem adição de $\mathrm{NH}_{3}$ foi inferior $(56,3 \%)$ ao tratamento com $4 \%$ de $\mathrm{NH}_{3}$ (64,57\%). Nas condições desse estudo, conclui-se que a amonização do bagaço de cana-de-açúcar provocou alterações na fração fibrosa do volumoso e contribuiu para o aumento dos coeficientes de digestibilidade e consumo da fibra em detergente neutro, fibra em detergente ácido e celulose.
\end{abstract}

PALAVRAS-CHAVE: Amonização. Digestibilidade. Ruminantes.

\section{SHEEP FED WITH SUGARCANE BAGASSE TREATED WITH ANHYDROUS AMMONIA}

\begin{abstract}
Among the existing co-products, crushed sugarcane bagasse is noteworthy, since the country has an annual production of approximately 75 million tons. The sugarcane bagasse from sugar, alcohol or cachaça mills is an issue, since it is underused and is often burned in open air, while it could be used as ruminant feed. This study assesses the effects of the addition of anhydrous ammonia $\left(\mathrm{NH}_{3}\right)$ on the nutritional value of sugarcane (Saccharum officinarum L.) bagasse in four adult, male, mixed breed, castrated sheep, with $40.75 \mathrm{~kg}$ initial weight, kept in individual metabolism cages, with mineral supplement and water ad libitum. Four isoproteic diets have been tested and fed to the animals in a $4 \times 4$ Latin square design. These treatments were: Diet 1 - Sugarcane bagasse in natura; Diet 2 - Sugarcane bagasse $+2 \% \mathrm{NH}_{3}$, based on dry matter $(\mathrm{DM})$; Diet 3 - Sugarcane bagasse $+3 \% \mathrm{NH}_{3}$, based on DM; Diet 4 - Sugarcane bagasse $\mathrm{NH}_{3}+4 \%$ based on DM. The diets were fed twice a day, in the morning and afternoon, always at 08:00 am and 04:00 pm, respectively. For the determination of apparent digestibility, fecal collection bags were used and samples of food and leftovers were daily measured. Urine collection was performed using buckets placed under the metabolism cages. These buckets contained 100-ml hydrochloric acid $(2 \mathrm{~N} \mathrm{HCl})$ to avoid fermentation and nitrogen loss. Feed, leftover, feces and urine samples were stored in plastic bags under refrigeration, separated by treatment and trial period. After thawing the feces, diet and leftover samples were pre-dried at 55 ${ }^{\circ} \mathrm{C}$ for 72 hours and then ground in a mill with 1.00 - $\mathrm{mm}$ mesh sieve. Urine samples were previously dried in an oven at $55^{\circ} \mathrm{C}$ stored in plastic bags and then placed in a calorimeter for determining the energy content. The results of consumption and digestibility were subjected to analysis of variance test, followed by Student-Newman-Kewls test with a 5\% significance level.
\end{abstract}

DOI: https://doi.org/10.25110/arqvet.v17i4.2014.5029

${ }^{1}$ Zootecnista. Instituto Federal de Educação, Ciência e Tecnologia do Acre - IFAC. Rua Antônio Nicácio Teixeira, nº. 821. Bairro da Pista. CEP: 69.940-000 Sena Madureira - Acre. dayanazoo@yahoo.com.br. 
The intake and digestibility of dry matter (DM), crude protein (CP), gross energy (GE) and metabolizable energy (ME) did not differ between treatments $(\mathrm{P}>0.05)$. The digestibility and intake expressed in $\left(\mathrm{g} / \mathrm{kg}^{0.75}\right)$ of neutral detergent fiber (NDF) were 51.1 and 17.2, 50.9 and 26.1, 52.14 and 19.2, 58.3 and 21.0. The digestibility of acid detergent fiber (ADF) in the 4\% $\mathrm{NH}_{3}$ treatment was higher (59.5\%) than the treatment with the addition of $\mathrm{NH}_{3}(50.9 \%)$. The digestibility of cellulose without addition of $\mathrm{NH}_{3}$ was lower (56.3\%) than the treatment with $4 \% \mathrm{NH}_{3}$ (64.57). In this study, it can be concluded that the ammoniated sugarcane bagasse led to changes in the fiber roughage and contributed to the increased consumption and digestibility of neutral detergent fiber, acid detergent fiber and cellulose.

KEYWORDS: Ammoniation. Digestibility. Ruminants.

\section{OVINOS ALIMENTADOS CON BAGAZO DE CAÑA DE AZÚCAR TRATADO CON AMONÍACO ANHIDRO}

RESUMEN: Entre los coproductos existentes, el bagazo de caña de azúcar merece destaque, visto que es producido todo el año en el país, cerca de 75 millones de toneladas por año. Este bagazo proveniente de usinas de azúcar, alcohol o aguardiente constituye un problema, por ser poco utilizado, con frecuencia se queman al aire libre, mientras podría ser utilizado en la alimentación de rumiantes. Este estudio tuvo como objetivo evaluar el efecto de la adición de amoníaco anhidro $\left(\mathrm{NH}_{3}\right)$ en el valor nutritivo del bagazo de caña azúcar (Saccharum officinarum L.) para cuatro carneros machos adultos, castrados, sin raza definida, con peso inicial de 40,75 kg en jaulas individuales para el metabolismo, con sales minerales y agua $\mathrm{ad}$ libitum. Cuatro dietas isoproteicas han sido testadas y suministradas a los animales en un delineamiento en cuadrado latino 4x4, siendo: Dieta 1 - Bagazo de caña de azúcar "in natura", Dieta 2 - Bagazo de caña de azúcar $+2 \% \mathrm{NH}_{3}$, con base en la materia seca (MS), Dieta 3 - Bagazo de caña de azúcar $+3 \% \mathrm{NH}_{3}$, basado en MS, Dieta 4 - Bagazo de caña de azúcar + $4 \%$ de $\mathrm{NH}_{3}$, basado en la MS. Las dietas eran suministradas dos veces al día en el período de la mañana y tarde siempre en los horarios de ocho y 16 horas, respectivamente. Para la determinación de la digestibilidad aparente se utilizaron bolsas de plástico para recogido de heces, muestras de los alimentos y las sobras eran mensuradas diariamente. La recolección de orina se realizó mediante cubos ubicados en las jaulas de metabolismo, los cubos contenían $100 \mathrm{ml}$ de ácido clorhídrico ( $\mathrm{HCl} 2 \mathrm{~N}$ ) para evitar la fermentación y la pérdida de nitrógeno. Las muestras recolectadas de alimentos, sobras, heces y orina fueron acondicionadas en recipientes plásticos y conservadas en refrigeración, separando las muestras por tratamiento y período de prueba. Después de descongelar las muestras de heces, de la dieta y sus respectivas sobras fueron pre-secadas en estufa a $55^{\circ} \mathrm{C}$ durante 72 horas y, luego, molidas en molino con tamiz de malla de $1,00 \mathrm{~mm}$. Las muestras de orina fueron previamente deshidratadas en estufa a $55^{\circ} \mathrm{C}$ almacenadas en recipientes plásticos y posteriormente puestas en calorímetro, para determinación del contenido energético. Los resultados del consumo y la digestibilidad fueron sometidos a análisis de varianza, seguido de post test Student-Newman-Kewls con nivel de significancia de 5\%. El consumo y la digestibilidad de la materia seca (MS), proteína cruda (PC), energía bruta (EB) y energía metabolizable (EM) no fue diferente entre los tratamientos (P> $0,05)$. La digestibilidad y el consumo expreso en $\left(\mathrm{g} / \mathrm{kg}^{0,75}\right)$ de fibra en detergente neutro (FDN) fueron de 51,1 y 17,2, 50,9 y $26,152,14$, y 19,2, 58,3 y 21,0. La digestibilidad de la fibra en detergente ácido (FDA) en el tratamiento con $4 \%$ de $_{3}$ fue mayor $(59,5 \%)$ al tratamiento sin adición de $\mathrm{NH}_{3}(50,9 \%)$. La digestibilidad de la celulosa en el tratamiento sin adición de $\mathrm{NH}_{3}$ fue menor $(56,3 \%)$ al tratamiento con $4 \% \mathrm{de} \mathrm{NH}_{3}(64,57)$. En las condiciones de ese estudio, se concluye que el bagazo de caña de azúcar con amoníaco anhidro ha provocado alteraciones en la fracción fibrosa del volumen y ha contribuido para el aumento de los coeficientes de digestibilidad y consumo de la fibra en detergente neutro, fibra en detergente ácido y celulosa.

PALABRAS CLAVE: Amonificación. Digestibilidad. Rumiantes.

Recebido em: 22.02.2011

Aceito em: 20.12.2014 